\title{
Taking advantage of Ramadan and January in Muslim countries
}

\author{
Abstract \\ Anwar Halari* \\ The Open University Business School, The Open University, Milton Keynes, MK7 6AA, UK \\ Christine Helliar \\ School of Commerce, University of South Australia, Adelaide, SA 5001, Australia \\ David. M. Power \\ School of Business, University of Dundee, Dundee, DD1 4HN, UK \\ Nongnuch Tantisantiwong \\ Southampton Business School, University of Southampton, Southampton, SO17 1BJ, UK
}

Studies have shown that religious beliefs and practice play an important role in influencing share price behaviour. Evidence of a Ramadan effect has been documented in Muslim countries suggesting an increase in mean returns as well as a reduction in volatility during the ninth month of the Islamic calendar. In addition to the Ramadan effect, studies have also documented a January effect in Muslim countries. The current study investigates what happens when the Ramadan effect and the January effect occur at the same time. Controlling for the effects of financial crises and time-varying volatility in returns, the results for individual company data from four countries with sizeable Muslim populations indicate higher returns and lower volatility when these two effects overlap, except in one, arguably more Western country, Turkey.

Keywords: January effects; Ramadan effects; anomalous interaction; risk-adjusted returns

JEL classification: G14, G15

\section{Highlights:}

- This study investigates the interaction of the Ramadan and January effect.

- Individual company data for four Muslim-majority countries is investigated.

- Results suggest a magnification of the Ramadan effect in January except for Turkey.

- The interaction of Ramadan and January results in higher returns and lower volatility.

- The impact, however, varies across countries and from one sector to another. 


\section{Introduction}

Several studies have reported evidence of predictable patterns in stock markets at certain times of the day (Harris, 1986), week (Jaffe and Westerfield, 1985) or month of the year (Gultekin and Gultekin, 1983) which contradicts the efficient markets hypothesis. For instance, calendar patterns have been reported in a large number of studies which suggest that share price changes are not random. The well-known January effect is one of the best documented of these calendar anomalies. This effect suggests that returns in the month of January are higher, on average, compared to returns in other months. These higher returns in January have been detected in developed as well as emerging markets, and importantly in Muslim emerging markets.

Recently, a growing number of academics are examining whether returns vary in a systematic fashion for calendars such as the Islamic calendar ${ }^{1}$ (Al-Hajieh et al., 2011; Bialkowski et al., 2012; Al-Khazali, 2014; Halari et al., 2015; Al-Khazali et al., 2017; Wasiuzzaman, 2018). The Islamic calendar has 12 months but, unlike its Gregorian counterpart, these months are based on the lunar cycle. The Islamic year is therefore about 11 days shorter than the Gregorian year meaning that the Islamic calendar moves relative to the Gregorian calendar $^{2}$. Over a 32/33-year cycle, each Islamic month falls in a specific Gregorian month for about 5-6 consecutive years. For example, in 2017 the $1^{\text {st }}$ day of the ninth month in the Islamic calendar (Ramadan) fell at the end of May and it was 32 years ago, in 1985 when the $1^{\text {st }}$ day of Ramadan previously occurred during May. The month of Ramadan continued to overlap with May until 1989; it will be 2022 before Ramadan stops overlapping with the month of May and starts to occur in the month of April.

\footnotetext{
${ }^{1}$ Muslim countries use the Islamic calendar for religious activities and holidays whereas the Gregorian calendar is used for business.

${ }^{2}$ The beginnings and endings of an Islamic calendar month are determined by the sighting of the crescent moon. The 12 Islamic months are: Muharram, Safar, Rabiul Awwal, Rabiul Thani, Jamatul Awwal, Jamatul Thani, Rajab, Shaban, Ramadan, Shawwal, Zil Qa'ad and Zil Hajj.
} 
As with the Gregorian calendar, studies have shown evidence of predictability in share returns based on the Islamic calendar; for example, returns tend to be higher and the volatility of share price changes lower in the ninth month - Ramadan. This effect has been linked to the faith-based experiences of Muslim investors at certain times of the Islamic calendar which influence their decision-making processes (Al-Ississ, 2010)․․ More specifically, studies have linked share price increases in Ramadan to positive investor sentiment (Al-Ississ, 2010; Bialkowski et al., 2012; Al-Khazali et al., 2017); they have also attributed a decline in share return volatility to a reduction in trading activity during this month (Husain, 1998; Seyyed et al., 2005; Mustafa, 2008). For instance, Halari et al. (2015) note that business activity slows down during Ramadan in Muslim countries as people devote more time to religious activates and fasting. Recently, Ali et al. (2017) investigated the impact of Muslim Holy Days in Asian financial markets (including Pakistan and Turkey) from 2001 to 2014 and concluded that both Islamic and Gregorian calendar anomalies exist in Asian markets.

This study adds to the literature by investigating whether there is an interaction between any Ramadan effect from the Islamic calendar and a January effect from the Gregorian calendar. To date, these two anomalies have usually been studied in isolation; only Tantisantiwong et al. (2017) has recognised that the Ramadan and January effects overlap from time to time. The current paper addresses these issues by first investigating whether the Ramadan effect exists in the mean and volatility of equity returns for 428 firms across four countries with predominantly Muslim populations: namely, Indonesia, Jordan, Pakistan and Turkey. It then examines whether there is any interaction between Ramadan and January effects in the mean and volatility of returns when the Islamic month of Ramadan falls in January. Moreover, individual firm data were chosen and sectorial analysis was conducted in order to provide a comprehensive approach to the study and to investigate whether any Ramadan or January effect

\footnotetext{
${ }^{3}$ Studies as far back as Weber (1930) noted that religious practices can impact a country's economic development
} 
is specific to certain sectors. Since this study uses data which spans the recent financial crises, the findings of any calendar effects may be overstated; a higher return or lower volatility in the month of Ramadan when it does or does not overlap with January may be due to the calendar effects as well as the effect of financial crises. To address this issue, the paper controls for the effects of other Islamic months and recent financial crises, namely the Asian Financial Crisis (AFC) and the Global Financial Crisis (GFC) and employs an Exponential Generalised Autoregressive Conditional Heteroscedasticity (EGARCH) model to investigate whether equity returns for the four countries analysed behave differently on days when Ramadan falls in January.

The next section reviews the literature on calendar anomalies focusing, in particular, on studies that examine January and Ramadan. Section 3 describes the data used and the sample selected while Section 4 outlines the methodology. Section 5 discusses the results from our analysis of the data while Section 6 concludes.

\section{Literature Review}

Perhaps some of the most frequently researched anomalies in financial markets relate to calendar regularities which suggest that share returns are higher than average in certain months, on certain days or at specific times of year; these regularities provide investors with an opportunity to outperform the market on a consistent basis which contradicts the efficient market hypothesis (EMH).

The focus of the current investigation is the month of Ramadan in the Islamic calendar and the month of January in the Gregorian calendar. Several authors have investigated these

calendar anomalies separately. For example, in a Gregorian calendar context, Rozeff and Kinney (1976) was one of the first papers to detect January seasonality in US share returns. They discovered that share returns in January were higher than the average in the other 11 
months of the year. Many other studies have followed their initial investigation and arrived at a similar conclusion. Different academics have attributed this statistical regularity to the tax system; they highlight that most US investors finalise their tax liabilities in December and January is the start of a new tax year (Dyl, 1977; Roll, 1983; Givoly and Ovadia, 1983; Jacobs and Levy, 1988) ${ }^{4}$. Interestingly, similar patterns have been noted in many international markets where December is not the tax year end. Brown et al. (1983), for instance, report above average monthly returns for January in Australia where the tax-year starts in July. Furthermore, Gultekin and Gultekin (1983) and Agrawal and Tandon (1994) find a monthly seasonal pattern in many international markets with different taxation systems.

Both Islamic and Gregorian calendar effects have been investigated in a Muslimcountry context, for example, Pakistan. Husain (1998) was one of the earliest studies to investigate whether a Ramadan effect was present in the share prices of Pakistani listed firms. The author analysed 36 individual shares, 8 sector indices and a general market index over a period from 1989 to 1993 . He reported no significant change in average returns during Ramadan; however, a significant decline in return volatility was uncovered during the month of Ramadan. One criticism that has been levelled at Husain (1998) is that the relatively old data was only analysed for a fairly short time period (5 years). Using a relatively recent time frame, Mustafa (2008) also reported a significant decline in return volatility for Pakistani equities during the month of Ramadan. Majeed et al. (2015) investigated Islamic calendar anomalies in the Pakistani stock market using the KSE-100 index for the period of 2001 to 2012. Applying a simple OLS method, the authors revealed that Ramadan has a significant positive impact on the stock returns in Pakistan. The authors concluded that Islamic calendar anomaly exist in Pakistani stock market.

\footnotetext{
${ }^{4}$ These studies suggest that investors sell shares in December to minimise the tax on capital gains and purchase the equities again in January resulting in a higher demand for shares in January which results in a higher share return.
} 
Turning from the Islamic to the Gregorian calendar effect in Pakistan, a study by Ali and Akbar (2009) documented no monthly Gregorian calendar effect in the returns for the Karachi Stock Exchange (KSE) 100 index over the period 1991 to 2006. However, when analysing data over a different period, Rafique and Shah (2012) discovered that the highest average mean return for the KSE occurred in January. Hashmi (2014) reported a positive January effect in Pakistan over the period of 2004 to 2009. The author, however, suggested that the abnormal returns were not large enough to offset the transactions costs that an investor would have to incur when attempting to exploit this anomaly. Most recently, Ullah et al. (2016) reported a presence of a positive January effect in Pakistan for the period 2004 to 2014 using daily data of the KSE-100 index whilst Shamshir and Baig (2016) also found a significant January effect evident in all four indices in the Pakistani stock market. Thus in the case of an Islamic country such as Pakistan it appears that there may be a Ramadan effect and a January effect; the interaction between these two periods, when they occur at the same time, has been largely ignored in the literature.

Across a larger sample of countries, Keong et al. (2010) investigated security returns in 11 Asian countries using a first-order Generalised Autoregressive Conditional Heteroscedasticity (GARCH $(1,1))$ model over a 20-year period from 1990 to 2009 and reported a positive January effect in the majority Muslim country of Indonesia. A Ramadan effect has also been extensively studied in countries where Muslims constitute a majority of the population with mixed results regarding the existence of the Ramadan effect. For instance, Seyyed et al. (2005) documented a decline in volatility for the Saudi Arabian stock market over the period 1985 to 2000 .

A multi-country investigation by Abadir and Spierdijk (2005) uncovered a Ramadan effect in four nations in the Middle-East (Egypt, Jordan, Pakistan and Turkey) and two countries in the Far-East (Malaysia and Singapore). Similar findings were reported by Al- 
Hajieh et al. (2011) who tested for Islamic calendar anomalies in Middle Eastern stock market returns during the period 1992-2007. The authors reported that mean returns during Ramadan were higher than returns for the other 11 Islamic months in four out of the six Middle Eastern stock markets that they studied (including Jordan and Turkey). Almudhaf (2012) carried out a similar investigation in 12 countries with Muslim-majority populations and documented evidence of a Ramadan effect in equity returns of four counties in their sample, namely: Jordan, Kuwait, Pakistan and Turkey. More recently, Al-Khazali (2014) tested for a Ramadan effect in the stock returns of 15 Muslim countries (including the four markets studied in the current investigation) and reported that such an effect was present in most Muslim-majority countries. However, he argued that the magnitude of the effect diminished during the GFC indicating that the financial crises may have some impact on return behaviour during different months of the Islamic calendar. Bialkowski et al. (2012) also investigated whether returns varied in a systematic fashion across different months of the Islamic calendar in Muslim-majority countries. The data were drawn from 14 countries (including Indonesia, Jordan, Pakistan and Turkey) over the years 1989 to 2007. The authors reported that stock returns during Ramadan were significantly higher and less volatile than during the rest of the year; although a significant decrease in the share price volatility during Ramadan was not documented for Turkey. Their findings confirm the results presented by Al-Ississ (2010) from his analysis of data for 17 Muslim-majority countries (including the countries studied in this study) over a 20 -year period from 1988 to 2008. Al-Ississ reported that religious experience during the month of Ramadan appeared to have a significant positive effect on the equity returns in the countries studied. From his findings, he concluded that religious events affected the returns as well as trading volumes of Muslim-majority markets.

More recently, Al-Khazali et al. (2017) investigated data for 15 Muslim countries covering a 10-year period from 2006 until 2015. The authors confirmed that the month of 
Ramadan was associated with higher equity returns and lower volatility relative to other months of the Islamic calendar. Interestingly, the authors noted that the positive effect of Ramadan exceeded the negative effect of the GFC on stock markets of Muslim countries. Sonjaya and Wahyudi (2016) tested the persistence of the Ramadan effect in the stock returns in 10 Muslimmajority countries. The authors found that the Ramadan effect was present, but was not persistent with the exception of Kuwait, Oman and Tunisia. Shah et al. (2017), however, arrived at a different conclusion; the authors found no significant impact of Ramadan on returns or volatility in their study of three Islamic Global Equity Indices for a 5-year period from 2011 to 2015: the Dow Jones Islamic Market World Index, the MSCI AWI Islamic Index and the S\&P Global BMI Shariah Index. The authors argued that this result may arise because the Islamic Global Equity Indices that they examined are not tied to selected regions or countries with majority-Muslim populations.

Wasiuzzaman and Al-Musehel (2018) investigated the impact of Ramadan on the return and volatility of the stock markets of Saudi Arabia and Iran from 2008 to 2014. The results suggested that Ramadan had a significant positive impact on the mean returns and the volatility of the Saudi market, however, its influence on the Iranian market was found to be insignificant. Jaziri and Abdelhedi (2018) investigated Ramadan effect in six Arab stock markets (including Saudi Arabia) using daily prices of market indices over the period 2001 to 2016 . Their results indicated a positive effect during Ramadan in all the studied markets. Interestingly, the authors found the Ramadan effect more pronounced in the first 10 days and the second 10 days of Ramadan but not in the last 10 days where, according to Al-Ississ (2010), Muslims increase their intensity of worship.

More relevant to our study, Tantisantiwong et al. (2017) investigated Eastern (Islamic) and Western (Gregorian) calendar effects, including the effect of when Ramadan and January coincide and found that the results are more prominent in larger and more developed markets. 
The current study extends this analysis by investigating the sectoral impact of any interaction to provide a more holistic and comprehensive view of monthly patterns which may be present in share returns.

The above studies show that there may be a Ramadan effect and a January effect present in equities for certain countries. Each of these effects may result in positive mean returns as well as a reduction in volatility during the month of Ramadan, leading to a positive mean return per unit of risk (MRPUR). The days of Ramadan and January coincide at certain times because the Islamic calendar moves roughly 11 days back every year relative to the Gregorian calendar. If one is willing to accept the existence of a January and Ramadan effect - what happens if both effects are present on a trading day? The results may be magnified if the positive share returns witnessed for both months in prior studies occur at the same time. It may present an opportunity for investors to make higher risk-adjusted returns in the month of Ramadan when a part of (or, indeed, the whole month of) Ramadan falls in January. This investigation will enhance our understanding of the variability of any Ramadan effect and its interaction with January across industries. The current work therefore contributes substantially to the wider literature on Ramadan and January effects in the context of Muslim-majority markets.

The study employs firm-level data to facilitate a sectorial analysis of this phenomenon since any Ramadan or January effect may be specific to (or more pronounced in) certain sectors. For example, Halari et al. (2015) highlight how the hospitality sector is negatively impacted by Ramadan as all restaurants remain shut during the daylight hours of this month. A detailed inspection of the results in Husain (1998) suggests that the decline in return volatility for the chemical sector was more pronounced during Ramadan. These findings suggest that the Ramadan effect, if present, may be stronger in certain sectors and specific industries ${ }^{5}$. Thus,

\footnotetext{
${ }^{5}$ Jacobsen and Visaltanachoti (2009) whilst investigating the Halloween effect in the US stock market sectors arrived at a similar conclusion; they documented substantial differences across sectors in the magnitude of this holiday effect on share returns; the effect was negligible in consumption-related sectors whilst production sectors demonstrated a significant Halloween effect. Furthermore, Sharma and Narayan (2014) investigated the turn-of-
} 
the current study undertakes a sectorial analysis to determine if any sectors are more susceptible to the Ramadan or January effect or the interaction between the two effects. This is the first study to undertake a systematic sectorial analysis over a large sample in relation to the Ramadan and the January effects and the interaction between the two anomalies. The next section describes the data and research method employed in this study.

\section{Data and Sample Description}

Unlike most prior studies, the current paper examines daily share returns for individual firms listed on the stock markets of four Muslim-majority countries (Indonesia, Jordan, Pakistan and Turkey ${ }^{6}$ ) over the 19.5-year period from January 1, 1995 to June 30, 2014 ${ }^{7}$. These four countries are drawn from different geographic regions: Indonesia from South East Asia, Jordan from the Middle East, Pakistan from South Asia and Turkey from Europe. The selection criteria for choosing the countries were as follows: 1) the percentage of the population identifying themselves as Muslim had to be more than $80 \%$; 2) data had to be available from 1995; 3) the selected Muslim country had to be the largest market within the region (i.e. Pakistan was selected from South Asia instead of Bangladesh); and 4) the country had to have data for at least $10 \%$ of the listed firms on its stock market at the time when the price information was obtained and these firms had to account for at least $10 \%$ of the whole sample of this study.

\footnotetext{
the-month effect on 560 listed firms on NYSE and found that the effect varies with the sector the firm is located in and the size of each firm.

${ }^{6}$ Indonesia accounts for the largest Muslim population in the world closely followed by Pakistan whilst the proportion of the population which is Muslim is higher in Turkey than in other European countries (https://www.cia.gov/index.html). Jordan was the only Muslim-majority country in the Middle East that had data available for the period starting from 1995. We hope that an analysis of a large sample of individual firms located in Muslim-majority countries from various geographical locations around the world should make the findings generalisable to all majority-Muslim markets.

${ }^{7}$ Apart for Jordan, the share price information is obtained from Datastream. Jordan's data was collected directly from the stock exchange as Datastream does not have the data for Jordanian share prices before 2005. Furthermore, many firms were dropped because Datastream did not have price data adjusted for stock splits, scrip issues etc.
} 
The start date was chosen in order to have a long enough time frame to investigate the interaction between any Ramadan and January effect in share returns and volatility. While most prior studies use index observations in their analyses (Al-Hajieh et al., 2011; Almudhaf, 2012; Al-Khazali, 2014), we employ individual firm data in order to provide a comprehensive investigation of whether any Ramadan or January effect is specific to certain company sizes in specific sectors.

Table 1 reports information about the final sample of 428 firms that was used for this study. The sample firms were drawn from five main sectors: Finance, Industrial, Utilities, Consumer Goods and Chemical. ${ }^{8} \mathrm{~A}$ visual inspection of the table reveals that the largest number of the firms are located in Indonesia (38.58\%) while the smallest number are based in Jordan (10.51\%). All the sample firms were selected from companies listed on the main stock exchange of each country: the Indonesian Stock Exchange (IDX) for Indonesia, the Amman Stock Exchange (ASE) for Jordan, the Karachi Stock Exchange (KSE) for Pakistan and the Borsa Istanbul (BIST) for Turkey. All four markets are classed as emerging or frontier markets according to Standard \& Poor's (2016).

\section{[Insert Table 1 about here]}

The companies in the sample vary in size. For example, across the whole sample, the largest firm is Akbank which is listed on BIST with a market capitalisation of roughly USD 12 billion in August 2017, while the smallest company is Unicap Modaraba listed on KSE with a market capitalisation of approximately USD 0.174 million. Thus, a good mix of firm size is present. A majority of firms are in the Consumer sector; the one exception to this generalization

\footnotetext{
${ }^{8}$ For example, sectors such as Financial Services, Banks, Insurance, and Investments were grouped together under the heading of Finance Sector. Details for each sample firm and their individual sector is available upon request.
} 
is Jordan where most firms operate in the Finance sector. The Oil \& Gas and Energy (Utilities) sector has the largest market capitalisation in Pakistan while the Industrial sector has the largest market capitalisation in Indonesia. The Finance sector has the biggest market capitalisation for Jordan and Turkey.

Returns for this sample were computed as the first differences of the natural logarithm of prices. A total of 5086 observations (234 Gregorian months or 19.5 years) per firm were converted to Islamic dates for each country using a Gregorian-Islamic date convertor. ${ }^{9}$ The data in this study corresponds to the Islamic calendar period ranging from Shaban 1415 to Ramadan 1435 (241 months). As noted above, the Islamic calendar is approximately 11 days shorter than its Gregorian counterpart such that Islamic months vary by a few days each year on the Gregorian calendar.

\section{Methodology and hypotheses development}

An EGARCH model is used to investigate the mean and volatility of returns in January or Ramadan for the sample of 428 firms. This model captures any leverage effect which may be present and recognises that the market may respond differently to good and bad news ${ }^{10}$. The model includes control variables such as dummy variables to proxy for other Islamic monthly seasonal effects and financial crisis events.

To examine any monthly seasonality in share returns and volatility, the following EGARCH model was estimated:

\footnotetext{
9 The Gregorian-Islamic date convertor used was from the website called Islamic Finder (https://www.islamicfinder.org/islamic-date-converter/). These results were matched with other similar databases and any discrepancies investigated until a full Islamic calendar was determined. Islamic calendars issued in Islamic counties could not be used as these calendars are estimated for the coming years; they are forward looking when issued and may turn out to be incorrect based on the lunar cycle. The actual dates may have been different from these predictions based on actual sightings of the moon.

${ }^{10}$ Halari et al. (2015) suggested that good or bad news shocks may affect stock return volatility in Pakistan
} 


$$
\begin{gathered}
R_{j t}=\mu_{j}+a_{j} R_{j t-1}+\sum_{i=1}^{11} b_{i j} D_{i t}+c_{j} J A N_{t}+d_{j} D_{9} \times J A N_{t}+e_{j} A F C_{t}+f_{j} G F C_{t}+\varepsilon_{j t} \\
\log \left(h_{j t}\right)=\theta_{j}+\alpha_{j}\left[\frac{\left|\varepsilon_{j t-1}\right|}{\sqrt{h_{j t-1}}}-\sqrt{\frac{2}{\pi}}\right]+\beta_{j} \log \left(h_{j t-1}\right)+\gamma_{j} \frac{\varepsilon_{j t-1}}{\sqrt{h_{j t-1}}}+\sum_{i=1}^{11} \psi_{i j} D_{i t} \\
+\delta_{j} J A N_{t}+\phi_{j} D_{9} \times J A N_{t}+\tau_{j} A F C_{t}+\pi_{j} G F C_{t}
\end{gathered}
$$

Equation (1) is the mean equation where $R_{j t}$ is the stock return at time $\mathrm{t}$ for firm $\mathrm{j}$ examined. $\varepsilon_{\mathrm{jt}}$ is the residual term where $\varepsilon_{j t} \sim N\left(0, h_{j t}\right) . h_{j t}$ is the conditional variance. Equation (2) is the variance equation that captures the time-varying volatility in the return series. $\gamma$ is the coefficient that measures the asymmetric leverage effect. If $\gamma \neq 0$, this implies that the impact of a shock is asymmetric; a negative coefficient for $\gamma_{j}$ suggests that bad news has a greater impact than good news and vice versa. If $\gamma_{j}$ is negative, $\gamma_{j} \varepsilon_{j t-1}$ in the fourth term of Equation (2) is positive (negative) when $\varepsilon_{j t-1}<0(>0)$ i.e. the volatility is higher (lower) with a negative (positive) shock.

The model is specified according to the Islamic calendar; 11 monthly dummy variables are included in the mean and variance equations for share returns to proxy for Muharram through Zil Qa'ad; thus, Zil Hajj was selected as the reference month against which returns and share price volatility in all the other months is compared. More specifically $D_{1 \mathrm{t}}$ has the value of 1 for all Muharram observations and 0 otherwise, $D_{2 t}$ has the value of 1 for all Safar observations and 0 otherwise, and so on. Thus, $D_{9 t}$ has the value of 1 for all Ramadan observations and 0 otherwise. In addition, both equations include a dummy variable for January where $J A N=1$ for all January observations and 0 otherwise. The model also includes an interaction term to capture the interaction between any January and Ramadan effects $\left(D_{9} \times\right.$ $J A N)$. Furthermore, to control for the effect of the financial crises, two dummy variables called $A F C$ and GFC are introduced into both equations. In accordance with the dates provided by 
the International Monetary Fund (IMF), the value of the $A F C$ dummy variable is equal to 1 for the period from March 3, 1997 to July 31, 1999 and 0 for other observations ${ }^{11}$. The value of GFC is equal to 1 for the period from 15 September 2008, when Lehman Brothers filed for bankruptcy, onwards and 0 otherwise. These financial crises are well documented in the literature and there is evidence that all four markets were affected by either or both of the AFC and GFC (Al-Khazali, 2014). Hence, these crises are controlled for in the current investigation. The main hypotheses examined in this paper are as follows:

$\mathrm{H}_{1}\left(\mathrm{H}_{2}\right)$ : A positive (negative) Ramadan effect on stock returns (return volatility) exists after controlling for other Islamic monthly seasonal effects and the impact of financial crises $\left(\mathrm{H}_{1}\right.$ : $\left.b_{9 j}>0, \mathrm{H}_{2}: \psi_{9 j}<0\right)$;

$\mathrm{H}_{3}\left(\mathrm{H}_{4}\right)$ : A positive January effect on stock returns (return volatility) exists after controlling for other Islamic monthly seasonal effects and the impact of financial crises $\left(\mathrm{H}_{3}: \mathrm{C}_{j}>0, \mathrm{H}_{4}: \delta_{j}>0\right)$; $\mathrm{H}_{5}\left(\mathrm{H}_{6}\right)$ : An interaction exists between the Ramadan and January effects on stock returns (return volatility) when Ramadan falls in January and after controlling for other Islamic monthly seasonal effects and the impact of financial crises $\left(\mathrm{H}_{5}: d_{j} \neq 0 ; \mathrm{H}_{6}: \phi_{j} \neq 0\right)$.

These hypotheses emerge from an analysis of the literature. Their testing is facilitated by the EGARCH model, which is estimated by using a Quasi Maximum Likelihood (QML) approach with the Berndt, Hall, Hall and Hausman (BHHH) algorithm (Berndt et al., 1974). The results are discussed in the next section.

\footnotetext{
${ }^{11}$ The chronology is available at http://www.imf.org/external/pubs/ft/op/opfinsec/.
} 


\section{Results}

\subsection{Descriptive analyses}

Table 2 shows the percentage of firms for which the mean return, standard deviation of returns and MRPUR in Ramadan is one of the best three of the 12 Islamic calendar months. The first six columns relate to those years when the Islamic month of Ramadan fell between February and December while the next six columns relate to those years when Ramadan occurred, at least in part, in January. When Ramadan and January occurred together, firm performance in the month of Ramadan is better than when the two months do not overlap in 16 out of the 20 instances. More specifically, across the five sectors from the four countries, more firms have Ramadan as one of the best performing three months of the Islamic calendar when it occurs in January, than when it falls in February to December ${ }^{12}$. In particular, all sectors in Turkey perform better when Ramadan overlaps with January than when it does not. However, a different picture emerges when the standard deviation data are examined. In only 5 of the 20 sector/country cases are stock returns in the month of Ramadan less volatile when it overlaps with January. As a result, in 15 out of 20 cases, the MRPUR is higher during the years when the two months occur at the same time relative to when they do not. The exceptions to this generalisation are: (i) the utilities sector in Indonesia in which fewer firms have a higher MRPUR ratio in the month of Ramadan when it overlaps with January; and (ii) the industrial and consumer sectors in Jordan and the utilities and chemical sectors in Pakistan where there is no difference between overlapping and non-overlapping years. In particular, most firms perform better in Ramadan if that Islamic month falls in January for all sectors in Turkey. This finding suggests that the interaction between Ramadan and January tends to push the returns

\footnotetext{
${ }^{12}$ The exceptions to this generalisation are (i) the utilities sector in Indonesia and the chemical sector in Pakistan that have less firms with stock returns in the month of Ramadan as one of the best three of the twelve Islamic months during the overlapping years, and (ii) the financial and industrial sectors in Jordan that have the same percentage of firms in both periods.
} 
up without always reducing the risk level; nevertheless, the increase in returns is greater than the increase in risk. As a result, MRPUR ratios increase.

The Chi-square test results confirm these findings. The results indicate that the association between Ramadan and January does not vary significantly with sectors, but varies with countries. In other words, whether the percentage of firms with high MRPURs in the month of Ramadan is greater when Ramadan falls in January than when it falls in February to December depends on the stock market where the companies are listed $(\chi=100.88, p=0.00)$, but does not depend on the sector to which the companies belong $(\chi=6.62 p=0.157)$.

\section{[Insert Table 2 about here] \\ [Insert Table 3 about here]}

Table 3 reports the percentage of firms for which the mean as well as the MRPUR (SD) was higher (lower) during Ramadan when it overlapped with January relative to when it did not. An analysis of this table reveals that the MRPUR ratios for the month of Ramadan are usually higher when January and Ramadan overlap. The effect of this interaction varies across markets. The second column of Table 3 suggests that the complement between the Ramadan and January effects in share returns is more prominent in Turkey than in other countries. In the overlapping period, the Ramadan effect in the volatility of returns is enhanced for the Jordanian market; in Jordan, every utility company experienced a lower standard deviation in the month of Ramadan during years when Ramadan and January overlapped than when they did not. The second column of Table 3 shows that this lower SD in Jordan is enough to outweigh the lower returns in those years when the two months overlap, resulting in a higher percentage of firms with an increased MRPUR ratio. For Turkey, the risk is not lower for most companies when 
January and Ramadan overlap, but the higher mean return is enough to compensate for the higher risk level; as a result, most firms earn a higher MRPUR.

Across all five sectors, it seems that the Ramadan and January effects reinforce one another according to the mean returns. An inspection of Table 3 reveals that firms in the financial sector are least affected by the interaction between Ramadan and January than companies in other sectors for both mean and MRPUR values, but the opposite is found for SD values. That is, although the incremental effect of January on Ramadan in share returns may be relatively small in this sector, the incremental effect in return volatility is relatively large. Although the percentages with lower SD values during overlapping years is relatively small in most sectors, this is not the case for all countries; this suggests that firms with a lower return volatility in the month of Ramadan when it falls, at least in part, in January depends on the market in which the firm is listed.

\section{[Insert Table 4 about here]}

Next, we rank the Islamic months by their performance based on the MRPUR ratio with the best performing month ranked as "1" and the worst performing month is ranked as " 12 ". Table 4 shows that, even in years when Ramadan and January do not overlap, equities in Ramadan generally perform better than in any other month of the Islamic calendar in Jordan and Pakistan; this is especially the case for financial and consumer firms listed on the ASE and utility firms listed on the KSE. In addition, the second column in Table 4 highlights that when Ramadan occurs at the same time as January, the ranking of Ramadan, in terms of the average MRPUR across all firms, improves in all countries with the exception of Indonesia; the ranking also improves in all sectors in Pakistan and Turkey, three sectors in Jordan and two sectors in Indonesia. The sector for which the MRPUR ranking in Ramadan improves across all the 
sample countries is chemicals, which tends to have a lower level of foreign investment compared to the other four sectors ${ }^{13}$. It is worth noting that the results in Table 4 confirm the findings of Table 3. That is, the incremental effect of January on MRPURs in the financial sector is smaller than in other sectors. Also, the MRPURs for financial firms in the month of Ramadan are ranked higher if Ramadan overlaps with January in Pakistan and Turkey, but are ranked lower in Indonesia and Jordan ${ }^{14}$.

\section{[Insert Table 5 about here]}

Overall, there are Ramadan effects in stock returns and these effects are magnified when Ramadan overlaps with January. Even though the impact of Ramadan on risk is not as pronounced when Ramadan falls in January, the MRPUR in the month of Ramadan is higher when Ramadan falls in January in almost all sectors.

Because Ramadan overlapped with January during 1996-2000, around the time when the AFC occurred (1997-1999), any increase in MRPUR ratios during this time period may be attributable to the AFC rather than any calendar anomaly. Therefore, we now analyse the interaction between a Ramadan effect and a January effect by controlling for other factors such as time-varying volatility and financial crises. The results from this analysis are presented in Tables 5-7. The Ramadan-January interaction effects on stock returns and volatility are examined using an EGARCH $(1,1)$ model by testing the significance of coefficients for $D_{9} \times$ $J A N$ in Equations (1) and (2). If coefficients for this term are significantly positive or negative in Equations (1) and (2), the hypotheses that there is an interaction between the Ramadan and January effects on stock returns and (return volatility) when Ramadan falls in January is

\footnotetext{
${ }^{13}$ Statistics on foreign investment can be found on http://www.oecd.org/.

${ }^{14}$ This analysis does not take account of other effects that may impact the share prices such as the effect of timevarying volatility, financial crises or the leverage effect. Section 5.2 takes account of these effects.
} 
supported. A positive coefficient in Equation (1) will indicate that positive Ramadan effect is amplified in share returns whilst a negative coefficient in Equation (2) will suggest that the negative Ramadan effect in return volatility is greater when Ramadan falls in January ${ }^{15}$.

\subsection{Estimation Results for the Control Variables}

Table 5 shows the results of the sample firms by market. Specifically, the top half of Table 5 shows the average coefficient values for the mean equation controlling for the effects of other Islamic months and financial crises. In addition to the mean values of coefficients, the percentage of significant coefficients is also reported. The bottom half of Table 5 reports the results for the variance equation (Equation 2). The average coefficient and the percentage of significant coefficients are provided for the whole sample (All) as well as for each country (Indonesia, Jordan, Pakistan and Turkey). Tables 6 and 7 show the results for the mean and variance equations, respectively, for each sector within a country; to conserve space, they report only the coefficients for lagged returns, the Ramadan effect, the January effect, the interaction between Ramadan and January effects, the two crises and the asymmetric effects of a shock.

Table 5 indicates that these markets are fairly inefficient since the lagged return variable is statistically significant in a large number of cases; the Indonesian stock market is the most inefficient market while the Turkish stock market is relatively more efficient. The percentage of significant coefficients for the lagged return variable is $81.76 \%$ for Indonesia and only $33.33 \%$ for Turkey. Table 6 shows that stock returns for most firms in all sectors of Indonesia and the financial sector of Pakistan are predictable using lagged return values.

\footnotetext{
15 The Ramadan effect when Ramadan falls in January is composed of the Ramadan effect (the coefficient for $\mathrm{D}_{9}$ ) and the interaction between the Ramadan and January effects on return volatility (a coefficient for $D_{9} \times J A N$ ). If both coefficients in Equation (1) are positive, then the Ramadan effect in share returns is amplified by the interaction between the Ramadan and January effects; if the coefficients in Equation (2) are negative, then the Ramadan effect in return volatility is amplified by the interaction between the two effects.
} 


\section{[Insert Table 6 about here]}

\section{[Insert Table 7 about here]}

In addition, the asymmetric effect of previous shocks on the current return volatility varies widely depending upon the stock exchange on which firms are listed. According to the results documented in Table 5, the leverage effect is least prominent in Turkey (where under $50 \%$ of the $\gamma_{j}$ coefficients are significant) and most prominent in Indonesia (where over $80 \%$ of the $\gamma_{j}$ coefficients are significant). Notably, the results in Table 7 suggest that good news tends to induce higher return volatility than bad news in all sectors within Indonesia and Jordan; the average value of $\gamma_{j}$ is positive. For Pakistan and Turkey, investors in financial and utility firms appear to be more sensitive to bad news than good news (the average value of $\gamma_{j}$ is negative), but it is the other way around for investors in industrial and consumer companies. For chemical firms, stock returns become more volatile when good news emerges in Pakistan, but less volatile when good news is disclosed in Turkey. The size of this leverage effect is largest in the utilities sector of Jordan, but the effect does not appear to be present for chemical equities traded in Jordan. In terms of the percentage of firms affected, the asymmetric effect of news on stock return volatilities is more prominent in the utilities sector; however, the average coefficient for utility firms across the four countries is equal to zero, indicating that on average the effect of shocks is neutral in this sector. The result suggests that there are differences in investor behaviours across the four stock markets and sectors, providing support for an analysis at the individual firm rather than at the aggregate market level.

The impact of financial crises on stock returns varies across the four countries being examined. Table 6 shows that firms listed on the ASE and the KSE earned lower returns during 
the AFC and the $\mathrm{GFC}^{16}$. By contrast, the results for firms listed in Turkey and Indonesia varied from one crisis to another; shares listed on the BIST (IDX) tended to have higher returns during the AFC (GFC) and lower returns during the GFC (AFC). This pattern may be related to the regional economy of the country being studied; Indonesia was probably affected more by the AFC since this was more prominent in Asia (Bastos and Caiado, 2011) while Turkey was impacted more strongly by the GFC crisis which was especially severe in Europe. At the time when Asian stock markets performed badly, there was capital flight from that region to other emerging markets including those in Eastern Europe. Likewise, Asian stocks became safehavens for the assets of global investors during the more recent GFC. The findings may also relate to the fact that foreign investment in Indonesia tends to come from Singapore, Japan and Malaysia while a sizeable amount of FDI in Turkey is invested from the European Union.

Overall, Tables 5-7 show that the impact of the two financial crises was more prominent in stock volatilities than in mean returns. In particular, about $90 \%$ of firms listed on these four stock markets were affected by both financial crises, but the specific impacts varied from country to country. The results reported in Table 5 show that while stock returns in Indonesia and Turkey were more volatile during the AFC, those in Jordan and Pakistan are less volatile. In contrast, the average stock returns in all four Muslim countries were less volatile during the GFC; the effect of the GFC on stock return volatility was most pronounced in the Indonesian stock market. In addition, the results in Table 7 show that the risk levels for all firms in Pakistan's utilities sector and Jordan's chemical sector were affected by both crises, implying that these two sectors are more sensitive to external shocks than other sectors.

\footnotetext{
${ }^{16}$ There are two possible reasons for this. One is that the ASE and the KSE were less connected to South East Asian stock markets during the AFC period. Another is that the main sources of capital flowing into Jordan and Pakistan are the US and the UK (See Bureau of Economic and Business Affairs (2014) and Zakaria (2008).
} 


\subsection{Ramadan effects}

The second column of Table 5 shows that daily stock returns tended to be higher, on average, in Ramadan relative to the other Islamic months with a coefficient of 0.1041 . However, this Ramadan effect was only significant for a minority of all companies; just $32 \%$ of firms listed on these four markets had significantly higher stock returns in the month of Ramadan. These results vary from one country to another with stock returns for the month of Ramadan higher than all of the other Islamic months for Jordan and Pakistan. In Indonesia, however, Ramadan had the second highest returns - after those of Rabiul Awwal (the $3^{\text {rd }}$ month) - while in Turkey 7 months have higher mean returns than Ramadan ${ }^{17}$. The second column of Table 6 shows that the incidence and size of the Ramadan effect varies across the five sectors. The Ramadan effect in stock returns is relatively more pronounced in the utilities sector in terms of the percentage of firms affected, but is more prominent in the chemical sector in terms of the size of the coefficient. The Ramadan effect is relatively small in Turkey ${ }^{18}$. Overall, the results in Table 6 suggest that, with the exception of the utilities sector, less than half of the sample firms in each sector have significantly higher stock returns in the month of Ramadan.

In Indonesia, Jordan and Pakistan, stocks have their lowest risk level in the month of Ramadan. The one exception is Turkey - but even here, conditional volatility for the month of Ramadan is the second lowest recorded. This finding confirms the results of Bialkowski et al. (2012) who documented that equity return volatility in the month of Ramadan was not the lowest in the Turkish stock market, but was the lowest in the other three markets being examined. Table 7 illustrates that, across all five sectors, equities traded in these Muslim countries are less volatile in the month of Ramadan. The chemical sector was most affected by Ramadan, in terms of the size of the reduction in return volatility and the percentage of firms

\footnotetext{
${ }^{17}$ Muharram (the $1^{\text {st }}$ month), Rabiul Thani (the $4^{\text {th }}$ month), Jamutul Awwal (the $5^{\text {th }}$ month), Rajab (the $7^{\text {th }}$ month), Shaban (the $8^{\text {th }}$ month), Shawwal (the $10^{\text {th }}$ ) and Zil Qa'ad (the $11^{\text {th }}$ month) are all higher than Ramadan.

${ }^{18}$ There is no evidence of the Ramadan effect in Turkey's chemical sector and there is very little evidence of the effect in Turkey's financial sector.
} 
with significant coefficients $(75 \%)^{19}$. Table 7 also shows that for each sector, Turkey has the fewest or second fewest firms for which stock returns are less volatile in the month of Ramadan.

Overall, there is support for Hypotheses 1 and 2 that there are Ramadan effects in stock returns and volatility. That is, returns increase and volatility falls during the $9^{\text {th }}$ month of the Islamic calendar; however, the effect on returns is less pronounced than the effect on volatility. Both effects are less prominent in Turkey and in the industrial sector. In terms of the size of these two effects, the Ramadan effect on returns (volatility) is largest in the utilities sector in Pakistan (the industrial sector in Jordan). The chemical sector in particular has a strong Ramadan effect.

\subsection{January effects}

The results in Table 5 show that, on average, firms listed on the ASE, KSE and BIST have higher returns in January, compared to other Gregorian months, whereas firms listed on the IDX have lower returns in January. According to the results documented in Table 6, stock returns for all sectors in Jordan, Pakistan and Turkey (except for Turkey's industrial sector and Jordan's financial sector) increase in January no matter which Islamic month the trading day falls in. However, the results vary across countries; the positive January effect is present for only $25 \%$ of firms in the utilities sector of Jordan, less than a quarter of firms in the financial sector in Pakistan and all sectors in Turkey.

The results presented in Table 5 indicate that stocks traded on the IDX, ASE and KSE have lower levels of risk in January; the exception is BIST where January is associated with higher levels of risk ${ }^{20}$. Table 7 documents the sectoral impact of the January effect on stock

\footnotetext{
${ }^{19}$ The Ramadan effect on stock return volatilities is present in all utility firms listed on the ASE, most of the financial firms listed on the IDX and the KSE, and most of the chemical firms listed on the IDX and the KSE which confirms the findings of Husain (1998).

${ }^{20}$ Table 5 shows that in these four Muslim countries, stocks traded in January have a higher risk level than in Ramadan.
} 
return volatility. Consistent with the results shown in Table 5, Table 7 reports that the average values of coefficients for January are positive in all sectors for Turkey but negative in most sectors for Indonesia, Jordan and Pakistan ${ }^{21}$. This finding indicates that returns of firms tend to be more volatile in January across the five sectors of Turkey, but less volatile in most sectors for the other three countries.

Therefore, the results support Hypothesis 3 (with some exceptions) that there are positive January effects in stock returns but fail to support Hypothesis 4 that there are positive January effects in stock returns volatility for the four Muslim countries considered in this study. The results show that returns increase and volatility declines during January; however, the effect on returns is less prominent than the effect on volatility. There are two exceptions to this generalisation: Indonesian firms have lower returns and lower risk in January while Turkish firms have higher returns and higher risk in January. Thus, there is partial support for our third and no support for our fourth hypotheses.

\subsection{Interaction between Ramadan and January effects}

The results in the previous section highlighted that there appears to be both a Ramadan effect and a January effect; we now examine whether there is an interaction between these two effects. If the coefficient term for $D_{9} \times J A N$ is positive or negative in Equation (1) and Equation (2), the hypothesis that interaction exists between the Ramadan and January effects on share returns and (return volatility) is supported. A positive coefficient in Equation (1) will suggest that stock returns are larger whilst a negative coefficient in Equation (2) will indicate that return volatility is lower when this $9^{\text {th }}$ month of the Islamic calendar falls in January.

The coefficient for the interaction term in the mean equation (Equation (1)) is positive in Table 5 for "All" countries. This result indicates that stock returns in Ramadan are higher

\footnotetext{
${ }^{21}$ The exceptions are the industrial sector in Indonesia and Pakistan and the chemical sector in Jordan.
} 
when it falls in January. The significance of the coefficient for the interaction term indicates the existence of the January effect for returns in Ramadan when Ramadan falls in January. The high positive values indicate that, in Muslim countries, the January effect in stock returns complement the Ramadan effect when Ramadan falls in January (except for Jordan).

Further, Table 6 shows that the complementary interaction between January and Ramadan effects are also present across all sectors (with the exception of the utilities sector in Indonesia and the financial sector in Jordan) when the months of Ramadan and January occur at the same time. The interaction effect is less significant than the January effect, except for the financial sector in Pakistan and Jordan and all sectors in Turkey. As a result, if Ramadan falls in January, more Turkish firms earn higher stock returns in the month of Ramadan. For example, in $22 \%$ of Turkish chemical firms, the significant interaction coefficient suggests an increment in a positive Ramadan effect in share returns of these firms in the month of January, so their share returns are higher in years when January and Ramadan overlap. When they do not overlap, none of the firms in Turkish chemical sector experiences higher returns in the month of Ramadan. It is also worth noting that the interaction effect for these two months is less pronounced in some sectors; only $6 \%(15 \%)$ of financial firms listed on the KSE (BIST) have significant coefficients for the January and interaction effects. Moreover, the interaction between the Ramadan and January effects is not significant for Jordan's industrial and utility firms $(0 \%)$. The small incidence of January and interaction effects in Turkey shown in Table 6 suggests that a higher return for most firms listed on the BIST during those years when Ramadan and January overlap (which is documented in Tables 2-3) is not significant when the AFC effect is controlled.

The negative coefficient for the interaction term in Table 5 also shows that in the case of Indonesia, Jordan and Pakistan, the interaction between the January and Ramadan effects can lead to much lower levels of risk in the month of Ramadan. Unlike other markets, equity 
risk in the Turkish stock market is the second lowest during the month of Ramadan in those years when Ramadan occurs in February to December, but the highest when Ramadan falls in January $^{22}$. The findings in Table 7 build on the results of Table 5 since they highlight that the risk of equities traded in the month of Ramadan are lower when it falls in January, compared to when it does not; the main exception to this generalisation is Turkey. The risk level is, on average, high in the month of Ramadan across all sectors in Turkey when Ramadan falls in January. This is consistent with the results shown in Tables 2-4. Thus, it could be concluded that the negative interaction between Ramadan and January results in a decline in return volatility (except in Turkey).

Overall, there is support for Hypotheses 5 and 6 since there is evidence of an interaction effect between Ramadan and January on share returns and return volatility. The results suggest that returns increase and volatility falls, apart from Turkey where returns increase but volatility also rises.

\section{Conclusion}

This paper examines a number of hypotheses about predictability in monthly returns for four countries where a majority of the population is Muslim. In particular, data for Indonesia, Jordan, Pakistan and Turkey are examined to investigate the Ramadan effect, the January effect and more importantly the effect when Ramadan and January occur at the same time, after controlling for the AFC and GFC and other Islamic monthly seasonality over a 20-Islamic year period. This study provides interesting insights regarding the Ramadan effect and its interaction with the January effect in stock returns and the volatility of equities listed in four Muslimmajority countries.

${ }^{22}$ Table 5 shows that January and interaction effects are more pronounced in return volatility than in share return. 
The findings generally provide some support for the hypotheses tested in this paper. There is support for Hypotheses 1 and 2 suggesting that returns increase and volatility falls during the month of Ramadan; however, the result is less prominent in Turkey and in the Industrial sector. The study also finds some support for Hypothesis 3 which suggests that there is January effect in stock returns for the four Muslim countries considered in this study with the exception of Indonesia. Regarding Hypothesis 4 (the positive January effect in return volatility), we find higher return volatility in January only in Turkey. Finally, there is support for Hypotheses 5 and 6 suggesting that an interaction exists between the Ramadan effect and January effect on share returns and return volatility. The results suggest that the Ramadan effect is amplified when it overlaps with January; returns are higher and volatility lower across firms from five different sectors when Ramadan falls in January. When the data are analysed by country, a similar pattern emerges in the different nations except for Turkey; when the Ramadan and January effects occur together, both returns and volatility are higher in Turkey. Nonetheless, the higher returns are greater than the increase in volatility, resulting in a higher MRPUR ratio in Turkey. Thus, our results indicate that although the calendar effect in share return and return volatility varies across the four markets and their sectors, the Ramadan and January effects together result in higher MRPUR ratios in all four markets.

We also find that the financial crises affect countries differently depending upon their regional grouping. The impact of good and bad news shocks also varies from one stock market to another. For example, the results indicate that the leverage effect is least prominent in Turkey and most prominent in Indonesia. Overall, the results show that as there is evidence of market inefficiency in all these markets. Investors should adopt an investment strategy to invest when Ramadan occurs at the same time as January. As this only happens for about 5-6 consecutive years roughly every 33 years, investors may also benefit by investing in Islamic stock markets in either in January or Ramadan. Hence, they have two opportunities a year in which to make 
abnormal returns. This knowledge may be useful for global investors whose investment involves equities listed on markets based in Muslim-majority countries. 


\section{References}

Abadir, K. M. \& Spierdijk, L. (2005). Liquidity Constraints and the Demand for Assets: An Application to the Festivity Effect. Working Paper, Available at SSRN: http://ssrn.com/abstract $=829484$

Agrawal, A. \& Tandon, K. (1994). Anomalies or illusions? Evidence from stock markets in eighteen countries. Journal of International Money and Finance, 13, 83-106

Al-Hajieh, H., Redhead, K. \& Rodgers, T. (2011). Investor Sentiment and Calendar Anomaly Effects: A Case Study of the Impact of Ramadan on Islamic Middle Eastern Markets. Research in International Business and Finance, 25, 3, 345-356.

Ali, I., Akhter, W. \& Ashraf, N. (2017). Impact of Muslim Holy Days on Asian stock markets: An empirical evidence. Cogent Economics and Finance, 5(1), 1-10.

Ali, S. \& Akbar, M. (2009). Calendar Effects in Pakistani Stock Market. International Review of Business Research Papers, 5, 389-404.

Al-Ississ, M. (2010). The Impact of Religious Experience on Financial Markets. Working Paper, Harvard University.

Al-Khazali, O. (2014). Revisiting fast profit investor sentiment and stock returns during Ramadan. International Review of Financial Analysis, 33, 158-170.

Al-Khazali, O., Bouri, E., Roubaud, D. \& Zoubi, T. (2017). The impact of religious practice on stock returns and volatility. International Review of Financial Analysis, Vol 52, $172-$ 189.

Almudhaf, F. (2012). The Islamic Calendar Effects: Evidence from Twelve Stock Markets. International Research Journal of Finance and Economics, 87, 185-191.

Bastos, J.A., Caiado, J. (2011). Recurrence quantification analysis of global stock markets, Physica A: Statistical Mechanics and its Applications, 390, 1315-1325.

Berndt, E.R., Hall, B.H., Hall, R.E., Hausman, J.A. (1974). Estimation and inference in nonlinear structural models. Annals of Economic and Social Measurement, 3, 653-665.

Bialkowski, J., Etebari, A. \& Wisniewski, T. P. (2012). Fast Profits: Investor Sentiment and Stock Returns during Ramadan. Journal of Banking and Finance, 36, 3, 835-845.

Brown, P., Keim, D. B., Kleidon, A. W. \& Marsh, T. A. (1983). Stock Return Seasonalities and the Tax-Loss Selling Hypothesis. Journal of Financial Economics, 12, 105-127.

Bureau of Economic and Business Affairs (2014). Investment Climate Statement, US Department of State.

Dyl, E. (1977). Capital Gains Taxation and Year-end Stock Market Behavior. Journal of Finance, 32, 165-175.

Ehm, C., Kaufmann, C. and Weber, M. (2014). Volatility inadaptability: Investors care about risk, but cannot cope with volatility. Review of Finance, 18(4), 1387-1423.

Givoly, D. \& Ovadia, A. (1983). Year-End Tax-Induced Sales and Stock Market Seasonality. Journal of Finance, 38, 1, 171-189.

Gultekin, M. N., \& Gultekin, N. B. (1983). Stock Market Seasonality - International Evidence. Journal of Financial Economics, 12, 469-481. 
Halari, A., Tantisantiwong, N., Power, D.M. \& Helliar, C. (2015). Islamic calendar anomalies: Evidence from Pakistani firm-level data. The Quarterly Review of Economics and Finance, $58,64-73$.

Harris, L. (1986). A transaction data study of weekly and intradaily patterns in stock returns. Journal of Financial Economics, 16(1), 99-117.

Hashmi, M.A. (2014). January Effect in Pakistan: A Time Series Analysis. Market Forces, 9(1), 37-44.

Husain, F. (1998). A seasonality in the Pakistani Equity market: The Ramadhan Effect. The Pakistan Development Review, 37, 1, 77-81.

Jacobs, B. I. \& Levy, K. N. (1988). Disentangling Equity Return Regularities: New Insights and Investment Opportunities. Financial Analysts Journal, 44, 3, 18-43.

Jacobsen, B. \& Visaltanachoti, N. (2009). The Halloween effect in US sectors. Financial Review, 44(3), 437-459.

Jaffe, J., \& Westerfield, R. (1985). The weekend effect in common stock market returns: The international evidence. Journal of Finance, 40(2), 433-454.

Jaziri, M. \& Abdelhedi, M. (2018). Islamic occasions and investor sentiment. International Journal of Islamic and Middle Eastern Finance and Management. In Press.

Keong, L., Yat, D. \& Ling, C. (2010). Month-of-the-year effects in Asian countries: A 20-year study (1990-2009). African Journal of Business Management, 4, 7, 1351-1362.

Majeed, U., Raheman, A., Sohail, M.K., Bhatti, G.A. \& Zulfiqar, B. (2015). Islamic calendar events and stock market reaction: Evidence from Pakistan. Science International, 27(3), 2559-2567.

Mustafa, K. (2008). The Islamic Calendar Effect in Karachi Stock Market, Proceedings of the Eighth International Business Research Conference, Dubai, UAE.

Ogden, J. P. (2003). The calendar structure of risk and expected returns on stocks and bonds. Journal of Financial Economics, 70(1), 29-67.

Rafique, M., \& Shah, Z. A. (2012). Investigating January Effect in Karachi Stock Exchange. International Research Journal of Finance and Economics, 92, 87-93.

Roll, R. (1983). Vast ist das? The turn of the year effect and the return premium of small firms. Journal of Portfolio Management, 9, 2, 18-28.

Rozeff, M. S. \& Kinney, W. R. (1976). Capital market seasonality: The case of stock returns. Journal of Financial Economics, 3, 379-402.

Seyyed, F. J., Abraham, A. \& Al-Hajji, M. (2005). Seasonality in Stock Returns and Volatility: The Ramadan Effect. Research in International Business and Finance, 19, 3, 374-383.

Shah, N., Qureshi, M.N. \& Aslam, Y. (2017). An Empirical Investigation of Islamic Calendar Effect in Global Islamic Equity Indices. International Journal of Economics and Finance, 9(6), 57-68.

Shamshir, M. \& Baig, J.M. (2016). Evidence of Monthly Anomalies in Pakistan Stock Exchange. Archives of Business Research, 4(6), 312-324.

Sharma, S.S. \& Narayan, P.K. (2014). New evidence on turn-of-the-month effects. Journal of International Financial Markets, Institutions and Money, 29, 92-108. 
Sonjaya, A.R. \& Wahyudi, I. (2016). The Ramadan effect: Illusion or reality?. Arab Economic and Business Journal, 11(1), 55-71.

Standard \& Poor's Annual Country Classification Consultation (2016). Available at: http://us.spindices.com/documents/index-news-and-announcements/20160602-spdjicountry-classification-consultation.pdf

Tantisantiwong, N., Halari, A., Helliar, C. \& Power, D. (2017). East meets West: When the Islamic and Gregorian calendars coincide. The British Accounting Review. In press.

Ullah, I., Ullah, S. \& Ali, F. (2016). Market Efficiency Anomalies: A Study of January Effect In Karachi Stock Market. Journal of Managerial Sciences, 10(1), 32-44.

Wasiuzzaman, S. \& Al-Musehel, N.A. (2018). Mood, religious experience and the Ramadan effect. International Journal of Emerging Markets, 13(1), 290-307.

Wasiuzzaman, S. (2018). Seasonality in the Saudi stock market: The Hajj Effect. The Quarterly Review of Economics and Finance, 67, 273-281.

Weber, M. (1930). The Protestant Ethic and the Spirit of Capitalism, New York: Scribner's.

Zakaria, M. (2008). Investment in Pakistan: a critical review. Munich Personal RePEc Archive Paper No. 11543. Available at: https://mpra.ub.uni-muenchen.de/11543/1/Paper_10.pdf. Accessed 17.06.16. 
Table 1 Sample by country and sector

\begin{tabular}{cccccccc}
\hline Countries & Finance & Industrial & Utility & Consumer & Chemical & $\begin{array}{c}\text { Total } \\
\text { Companies }\end{array}$ & $\begin{array}{c}\text { \% of } \\
\text { sample }\end{array}$ \\
\hline Indonesia & 29 & 24 & 11 & 67 & 17 & 148 & 34.58 \\
Jordan & 19 & 6 & 4 & 11 & 5 & 45 & 10.51 \\
Pakistan & 16 & 24 & 11 & 45 & 13 & 109 & 25.47 \\
Turkey & 20 & 37 & 10 & 50 & 9 & 126 & 29.44 \\
\hline Total & 84 & 91 & 36 & 173 & 44 & 428 & $\mathbf{1 0 0 . 0 0}$ \\
\hline
\end{tabular}

Note: This Table reports the sample used in this study by country and by sector over the 19.5 Gregorian (20 Islamic) year period. 
Table 2: A comparison of the performance of Ramadan vs other Islamic months

\begin{tabular}{|c|c|c|c|c|c|c|c|c|c|c|c|c|c|}
\hline & \multicolumn{6}{|c|}{ Non-overlapping years } & \multicolumn{6}{|c|}{ Overlapping years } & \multirow{2}{*}{$\begin{array}{c}\text { Interaction } \\
\text { effect \& } \\
\text { Country } \\
\text { Chi-square } \\
\text { stat.(p-Value) }\end{array}$} \\
\hline & All & Fin. & Ind. & $\begin{array}{c}\text { Sectors } \\
\text { Util. }\end{array}$ & Cons. & Chem. & All & Fin. & Ind. & $\begin{array}{c}\text { Sector } \\
\text { Util. }\end{array}$ & Cons. & Chem. & \\
\hline \multicolumn{13}{|l|}{ Indonesia } & \multirow{20}{*}{$\begin{array}{l}100.88 \\
(0.000)\end{array}$} \\
\hline Top 3 Mean & 17.01 & 17.86 & 8.33 & 36.36 & 16.42 & 17.65 & 22.44 & 21.43 & 20.83 & 9.09 & 23.88 & 29.41 & \\
\hline Bottom 3 SD & 32.00 & 35.71 & 37.50 & 18.18 & 31.34 & 29.41 & 30.60 & 28.57 & 25.00 & 27.27 & 28.36 & 52.94 & \\
\hline Top 3 MRPUR & 19.72 & 17.86 & 16.67 & 36.36 & 20.90 & 11.76 & 23.12 & 21.43 & 20.83 & 9.09 & 23.88 & 35.29 & \\
\hline Jordan & & & & & & & & & & & & & \\
\hline Top 3 Mean & 35.74 & 50.00 & 33.33 & 0.00 & 41.67 & 0.00 & 46.67 & 50.00 & 33.33 & 25.00 & 50.00 & 60.00 & \\
\hline Bottom 3 SD & 38.94 & 31.25 & 50.00 & 75.00 & 41.67 & 20.00 & 25.74 & 25.00 & 16.67 & 75.00 & 16.67 & 20.00 & \\
\hline Top 3 MRPUR & 37.78 & 50.00 & 33.33 & 0.00 & 50.00 & 0.00 & 49.31 & 56.25 & 33.33 & 25.00 & 50.00 & 60.00 & \\
\hline \multicolumn{13}{|l|}{ Pakistan } & \\
\hline Top 3 Mean & 42.43 & 31.25 & 45.83 & 63.64 & 35.90 & 54.55 & 57.57 & 50.00 & 50.00 & 72.73 & 64.10 & 45.45 & \\
\hline Bottom 3 SD & 36.90 & 31.25 & 45.83 & 9.09 & 38.46 & 45.45 & 25.71 & 25.00 & 25.00 & 27.27 & 30.77 & 9.09 & \\
\hline Top 3 MRPUR & 43.48 & 43.75 & 37.50 & 63.64 & 38.46 & 54.55 & 57.74 & 50.00 & 50.00 & 63.64 & 64.10 & 54.55 & \\
\hline \multicolumn{13}{|l|}{ Turkey } & \\
\hline Top 3 Mean & 15.87 & 15.00 & 24.32 & 0.00 & 16.00 & 0.00 & 92.06 & 90.00 & 94.59 & 90.00 & 90.00 & 100.00 & \\
\hline Bottom 3 SD & 0.79 & 0.00 & 2.70 & 0.00 & 0.00 & 0.00 & 2.38 & 5.00 & 0.00 & 0.00 & 4.00 & 0.00 & \\
\hline Top 3 MRPUR & 13.49 & 15.00 & 16.22 & 0.00 & 16.00 & 0.00 & 92.06 & 85.00 & 94.59 & 90.00 & 92.00 & 100.00 & \\
\hline \multicolumn{2}{|l|}{ Total Top 3 Mean } & 26.25 & 26.37 & 30.56 & 22.62 & 21.43 & & 50.00 & 59.34 & 52.78 & 54.76 & 52.38 & \\
\hline \multicolumn{2}{|l|}{ Total Bottom 3 SD } & 25.00 & 26.37 & 16.67 & 24.40 & 26.19 & & 21.25 & 14.29 & 25.00 & 20.83 & 26.19 & \\
\hline \multicolumn{2}{|l|}{ Total Top 3 MRPUR } & 28.75 & 23.08 & 30.56 & 25.60 & 19.05 & & 50.00 & 59.34 & 50.00 & 55.36 & 57.14 & \\
\hline \multicolumn{7}{|c|}{ Interaction effect and Sector Chi-square stat. (P-Value) } & \multicolumn{6}{|c|}{$6.62(0.157)$} & \\
\hline
\end{tabular}

Note: Table shows the percentage of firms, for which the mean value of stock returns and the mean return per unit risk (standard deviation) in Ramadan, compared to other Islamic months, are ranked as one of the top (bottom) three. Fin. stands for financial sector, Ind. for industrial sector, Util. for utilities sector, Cons. for consumer sector, and Chem. for chemical sector. Emboldened numbers indicate the sector of which performance in Ramadan is not improved in overlapping years. 
Table 3: The performance in Ramadan in overlapping versus non-overlapping years

\begin{tabular}{|c|c|c|c|c|c|c|}
\hline \multirow[b]{2}{*}{ Country } & \multirow[b]{2}{*}{ All } & \multicolumn{5}{|c|}{ Sectors } \\
\hline & & Finance & Industrial & Utilities & Consumer & Chemical \\
\hline \\
\hline \multicolumn{7}{|c|}{$\overline{\operatorname{Mean}^{\mathrm{NC}}}$} \\
\hline All & & 55.00 & 75.82 & 69.44 & 64.88 & 69.05 \\
\hline Indonesia & 47.619 & 32.14 & 70.83 & 27.27 & 46.27 & 58.82 \\
\hline Jordan & 41.860 & 25.00 & 16.67 & 75.00 & 50.00 & 80.00 \\
\hline Pakistan & 62.376 & 68.75 & 58.33 & 81.82 & 58.97 & 54.55 \\
\hline Turkey & 99.206 & 100.00 & 100.00 & 100.00 & 98.00 & 100.00 \\
\hline \multicolumn{7}{|l|}{$\mathrm{SD}^{\mathrm{C}}<1$} \\
\hline \multicolumn{7}{|l|}{$\overline{\mathrm{SD}^{\mathrm{NC}}}$} \\
\hline All & & 36.25 & 29.67 & 27.78 & 26.79 & 30.95 \\
\hline Indonesia & 23.810 & 28.57 & 29.17 & 9.09 & 17.91 & 41.18 \\
\hline Jordan & 86.047 & 93.75 & 83.33 & 100.00 & 83.33 & 60.00 \\
\hline Pakistan & 48.515 & 37.50 & 54.17 & 45.45 & 56.41 & 27.27 \\
\hline Turkey & 2.381 & 0.00 & 5.41 & 0.00 & 2.00 & 0.00 \\
\hline \multicolumn{6}{|c|}{ MRPUR $^{\mathrm{C}}>1$} & \\
\hline All & & 56.25 & 73.63 & 69.44 & 63.10 & 64.29 \\
\hline Indonesia & 43.537 & 32.14 & 62.50 & 36.36 & 40.30 & 52.94 \\
\hline Jordan & 46.512 & 37.50 & 33.33 & 75.00 & 41.67 & 80.00 \\
\hline Pakistan & 60.396 & 62.50 & 54.17 & 72.73 & 64.10 & 45.45 \\
\hline Turkey & 99.206 & 100.00 & 100.00 & 100.00 & 98.00 & 100.00 \\
\hline
\end{tabular}

Note: Table shows the percentage of firms, for which the mean value of stock returns and the mean return per unit risk (standard deviation) in Ramadan in overlapping years $(\mathrm{C})$, compared to non-overlapping years (NC), are higher (lower). Emboldened numbers are the sector of which performance in Ramadan is most improved when it overlaps with January. 
Table 4: MRPUR rankings for the month of Ramadan in overlapping and non-overlapping years

\begin{tabular}{|l|c|c|c|c|c|c|}
\hline \multicolumn{1}{|c|}{ Country } & \multirow{6}{|c|}{ Sectors } \\
\cline { 3 - 7 } & All & Finance & Industrial & Utilities & Consumer & Chemical \\
\hline Indonesia & & & & & & \\
Non-overlapping years & 6 & 5 & 12 & 4 & 6 & 11 \\
Overlapping years & 9 & 10 & 5 & 10 & 7 & 5 \\
Jordan & 1 & 1 & 2 & 10 & 1 & 12 \\
Non-overlapping years & 1 & 2 & 3 & 3 & 1 & 2 \\
$\begin{array}{l}\text { Overlapping years } \\
\text { Pakistan }\end{array}$ & 3 & 3 & 2 & 1 & 3 & 2 \\
Non-overlapping years & 1 & 1 & 1 & 1 & 1 & 1 \\
Overlapping years & 8 & 8 & 5 & 9 & 8 & 9 \\
Turkey & 1 & 1 & 1 & 1 & 1 & 1 \\
Non-overlapping years & & & & & & \\
Overlapping years & & & & & & \\
\hline
\end{tabular}

Note: This table shows the MRPUR rankings for the four countries across five sectors for the 19.5 Gregorian (20 Islamic) year period. 
Table 5: EGARCH Estimation Results

\begin{tabular}{|c|c|c|c|c|c|c|c|c|c|c|}
\hline \multirow[t]{2}{*}{ Variables } & \multicolumn{2}{|c|}{ All } & \multicolumn{2}{|c|}{ Indonesia } & \multicolumn{2}{|c|}{ Jordan } & \multicolumn{2}{|c|}{ Pakistan } & \multicolumn{2}{|c|}{ Turkey } \\
\hline & Coef. & $\%$ Sig & Coef. & $\%$ Sig & Coef. & $\%$ Sig & Coef. & \%Sig & Coef. & $\% \mathrm{Sig}$ \\
\hline \multicolumn{11}{|l|}{ Mean equation } \\
\hline $\mathrm{R}_{\mathrm{jt}-1}$ & -0.0232 & 61.08 & -0.0709 & 81.76 & 0.0160 & 56.10 & 0086 & 6.97 & -0.0074 & 33.33 \\
\hline Muha & 0784 & 38.92 & 0106 & .76 & -0.0171 & .15 & 0654 & 47.71 & 0.2005 & 41.27 \\
\hline Safar & 0.0342 & 27.59 & 0.0268 & 1.08 & -0.0323 & 12.20 & 0.1166 & 43.12 & -0.0068 & 15.08 \\
\hline Rabiul & 0.0792 & 32.55 & 0.0973 & 35.14 & 0.0102 & 19.51 & 0.1792 & 51.38 & -0.0060 & 17.46 \\
\hline Rabil & 0.0520 & 34.67 & 0.0130 & 35.14 & 0.0190 & 34.15 & 0.0430 & 41.28 & 0.1165 & 28.57 \\
\hline Jam & 0.0905 & 36.56 & 0.0741 & 33.78 & 0.0290 & 29.27 & 0.1165 & 40.37 & 0.1072 & 38.89 \\
\hline & 0.0299 & 33.25 & -0.0153 & 5.81 & -0.0317 & 31.71 & 0.1277 & 44.95 & 0.0185 & 20.63 \\
\hline Rajab & 0.0305 & 34.67 & -0.0711 & 32.43 & -0.0284 & 31.71 & 0.0563 & 41.28 & 0.1466 & 32.54 \\
\hline & & 33.02 & 0.0491 & 49 & -0.0207 & 26.83 & 0.0987 & 39.45 & 0.1035 & 25.40 \\
\hline Ra1 & 0.1041 & 31.84 & 0.0864 & 81 & 0.0342 & 29.27 & 0.1977 & 47.71 & 0.0667 & 14.29 \\
\hline & 0.0779 & 35.85 & -0.0276 & & 0112 & & 0.1800 & & 0.1352 & 31.75 \\
\hline & 0.0700 & 31.13 & 0.0348 & 43 & 0.0009 & 34.15 & 0.1361 & & 0.0767 & 17.46 \\
\hline Janu & & 34.43 & -0.0391 & 46.62 & 0.0800 & & 0.0729 & 30.28 & 0.0355 & 17.46 \\
\hline Ram & 0.1696 & 23.58 & 0.1858 & 27.70 & -0.0471 & 31.71 & 0.0845 & 14.68 & 0.2947 & 23.81 \\
\hline$\mu$ & -0.0611 & 36.08 & -0.0624 & 51 & -0.0097 & 36.59 & -0.1149 & 46.79 & -0.0299 & 23.81 \\
\hline AFC & -0.0796 & 38.44 & -0.1411 & & -0.0979 & 60.98 & -0.1381 & 39.45 & 0.0491 & 20.63 \\
\hline GFC & 00180 & 41.98 & 0.0995 & & -0.0432 & 58.54 & -0.0324 & 33.03 & -0.0113 & 19.84 \\
\hline \\
\hline & -0.0096 & 68.40 & -0.0541 & 75.68 & 0.0485 & 73.17 & 0.0193 & 80.73 & -0.0012 & 47.62 \\
\hline $\mathrm{Sa}$ & -0.0018 & 65.57 & -0.0364 & 69.59 & 0.0405 & & 0.0402 & 79.82 & -0.0114 & 50.00 \\
\hline & -0.0243 & 72. & -0.0826 & & -0.0179 & & 0.0482 & & -0.0205 & 61.11 \\
\hline & & 71.70 & -0.0233 & & -0.0131 & & -0.0143 & & -0.0178 & 59.52 \\
\hline & -0.0187 & 67.69 & -0.0162 & 74.32 & -0.0276 & 56.10 & -0.0547 & 82 & 0.0124 & 53.17 \\
\hline & -0.0174 & 72.64 & -0.0036 & & -0.0264 & 56.10 & -0.0387 & 77.98 & -0.0122 & 63.49 \\
\hline Raja & -0.0355 & 68. & -0.0664 & & -0.0257 & 73.17 & -0.0314 & 83.49 & -0.0060 & 44.44 \\
\hline & & 66. & -0.0 & & -0.0 & & 0.0011 & & -0.0135 & 47.62 \\
\hline & -0.0582 & 67.69 & -0.0 & 0 & -0.0 & 60.98 & -0.0618 & 75.23 & -0.0178 & 54.76 \\
\hline & 0.0144 & 72.88 & -0.0014 & 88.51 & -0.0380 & 58.54 & 0.0471 & 77.06 & 0.0216 & 55.56 \\
\hline Zil C & -0.0214 & 70.75 & -0.0606 & & -0.0467 & 75.61 & 0.0293 & 83.49 & -0.0111 & 59.52 \\
\hline & -0.0314 & 64.39 & -0.0565 & & -0.0243 & 65.85 & -0.0426 & 75.23 & 0.0056 & 42.06 \\
\hline & -0.2119 & 69.34 & -0.1536 & & -0.0957 & & -0.6588 & 77.06 & 0.0685 & 65.08 \\
\hline$\theta$ & 0.3294 & 86.09 & 0.5188 & 92.57 & 0.0140 & 75.61 & 0.5332 & 89.91 & 0.0331 & 78.57 \\
\hline AFC & 0.0385 & 88.44 & 0.1209 & 95.95 & -0.0348 & 78.05 & -0.0444 & 91.74 & 0.0372 & 80.16 \\
\hline GFC & -0.0825 & 90.80 & -0.1555 & 92.57 & -0.0169 & 85.37 & -0.0435 & 90.83 & -0.0518 & 90.48 \\
\hline & 年 & & 0.2677 & 100.0 & 0.3058 & 100.0 & 0.2573 & 100.0 & 0.2833 & 100.0 \\
\hline $\ln \left(\mathrm{h}_{\mathrm{t}-1}\right)$ & 0.7920 & 99.06 & 0.7537 & 99.32 & 0.8423 & 100.0 & 0.6874 & 97.25 & 0.9111 & 100.0 \\
\hline$\varepsilon_{j t-1}$ & 0.0087 & 67.22 & 0.0080 & 81.08 & 0.0196 & 63.41 & 0.0154 & 70.64 & 0.0001 & 21 \\
\hline
\end{tabular}

Note: This summary table shows the average coefficients for all sample firms. $\mu$ and $\theta$ represents the effect of Zil Hajj. Mean and Variance of the coefficients of lagged returns, Muharram - Zil Qa'ad, January, Ramadan and January interaction (Ramadan $\mathrm{x}$ January) are shown. AFC is a dummy variable representing the observations in the period of Asian Financial Crisis while GFC represents the Global Financial Crisis of 2008. To calculate the average coefficient, the insignificant coefficients are treated as zero. Coef. shows the average of coefficients whilst \%Sig shows the percentage of firms in the sector that has significant coefficients at 5 percent level. Emboldened numbers are exceptions (the result is different from the expectation) 
Table 6: EGARCH Results for Mean Equation: Sectorial Analysis by Country

\begin{tabular}{|c|c|c|c|c|c|c|c|c|c|c|}
\hline \multirow[t]{2}{*}{ Variables } & \multicolumn{2}{|c|}{ All } & \multicolumn{2}{|c|}{ Indonesia } & \multicolumn{2}{|c|}{ Jordan } & \multicolumn{2}{|c|}{ Pakistan } & \multicolumn{2}{|c|}{ Turkey } \\
\hline & Coef. & \%Sig & Coef. & $\%$ Sig & Coef. & \%Sig & Coef. & \%Sig & Coef. & $\%$ Sig \\
\hline \multicolumn{11}{|l|}{ Finance } \\
\hline $\mathrm{R}_{j \mathrm{t}-1}$ & -0.0450 & 67.07 & -0.1038 & 89.66 & 0.0005 & 47.06 & -0.0281 & 87.50 & -0.0120 & 35.00 \\
\hline Ramadan & 0.0968 & 43.90 & 0.0870 & 44.83 & 0.0324 & 76.47 & 0.2691 & 56.25 & 0.0280 & 5.00 \\
\hline January & 0.0010 & 35.37 & -0.0447 & 58.62 & -0.0004 & 47.06 & 0.0139 & 6.25 & 0.0581 & 15.00 \\
\hline Ramadan x Januar & 0.0911 & 28.05 & 0.0684 & 31.03 & -0.0720 & 58.82 & 0.1320 & 6.25 & 0.2299 & 15.00 \\
\hline $\mathrm{AFC}$ & -0.1250 & 53.66 & -0.2535 & 68.97 & -0.0851 & 52.94 & -0.1723 & 50.00 & 0.0651 & 35.00 \\
\hline GFC & -0.0107 & 45.12 & 0.0579 & 62.07 & -0.0584 & 64.71 & -0.0807 & 43.75 & -0.0137 & 5.00 \\
\hline \multicolumn{11}{|l|}{ Industrial } \\
\hline $\mathrm{R}_{j \mathrm{t}-1}$ & -0.0149 & 56.04 & -0.0396 & 75.00 & 0.0388 & 50.00 & -0.0041 & 62.50 & -0.0145 & 40.54 \\
\hline Ramadan & 0.0956 & 24.18 & -0.0166 & 12.50 & 0.0312 & 16.67 & 0.2250 & 41.67 & 0.0949 & 21.62 \\
\hline January & 0.0164 & 25.27 & -0.0438 & 37.50 & 0.0788 & 33.33 & 0.0886 & 29.17 & -0.0015 & 13.51 \\
\hline Ramadan & 0.1775 & 20.88 & 0.1519 & 33.33 & 0.0000 & 0.00 & 0.2257 & 12.50 & 0.1917 & 21.62 \\
\hline $\mathrm{AFC}$ & -0.0574 & 38.46 & -0.0846 & 37.50 & -0.1882 & 83.33 & -0.1705 & 54.17 & 0.0549 & 21.62 \\
\hline GFC & -0.0165 & 40.66 & 0.0689 & 62.50 & -0.0271 & 50.00 & -0.0697 & 25.00 & -0.0356 & 35.14 \\
\hline \multicolumn{11}{|l|}{ Utilities } \\
\hline $\mathrm{R}_{j \mathrm{t}-1}$ & -0.0008 & 58.33 & -0.0530 & 90.91 & 0.0081 & 25.00 & 0.0481 & 72.73 & -0.0008 & 20.00 \\
\hline Ramadan & 0.1670 & 52.78 & 0.0915 & 45.45 & -0.0693 & 25.00 & 0.3383 & 90.91 & 0.1560 & 30.00 \\
\hline Janua & 0.0340 & 44.44 & -0.0974 & 45.45 & 0.0323 & 25.00 & 0.0939 & 72.73 & 0.1135 & 20.00 \\
\hline Ramad & 0.1749 & 22.22 & 0.0072 & 18.18 & 0.0000 & 0.00 & 0.1819 & 27.27 & 0.4216 & 30.00 \\
\hline $\mathrm{AFC}$ & -0.0034 & 38.89 & -0.0219 & 54.55 & -0.0326 & 50.00 & -0.1131 & 27.27 & 0.1492 & 30.00 \\
\hline GFC & 0.0153 & 30.55 & 0.0886 & 45.45 & 0.0000 & 0.00 & -0.0508 & 36.36 & 0.0135 & 20.00 \\
\hline \multicolumn{11}{|l|}{ Consumer } \\
\hline $\mathrm{R}_{j \mathrm{t}-1}$ & -0.0243 & 60.82 & -0.0675 & 79.10 & -0.0005 & 55.56 & 0.0123 & 68.89 & -0.0036 & 30.00 \\
\hline Ramadan & 0.0808 & 27.48 & 0.0968 & 35.82 & 0.0683 & 22.22 & 0.0877 & 33.33 & 0.0553 & 12.00 \\
\hline January & 0.0101 & 33.92 & -0.0474 & 46.27 & 0.0235 & 55.56 & 0.0722 & 26.67 & 0.0290 & 20.00 \\
\hline Ramadan x January & 0.2246 & 22.81 & 0.2896 & 25.37 & 0.0376 & 33.33 & 0.0004 & 11.11 & 0.3731 & 28.00 \\
\hline $\mathrm{AFC}$ & -0.0975 & 33.92 & -0.1647 & 38.81 & -0.0794 & 77.78 & -0.1398 & 37.78 & 0.0272 & 16.00 \\
\hline GFC & 0.0524 & 42.69 & 0.1136 & 67.16 & -0.0097 & 77.78 & 0.0221 & 31.11 & 0.0090 & 14.00 \\
\hline \multicolumn{11}{|l|}{ Chemical } \\
\hline $\mathrm{R}_{j \mathrm{t}-1}$ & -0.0168 & 56.82 & -0.0840 & 82.35 & 0.0510 & 60.00 & 0.0310 & 38.46 & 0.0035 & 33.33 \\
\hline Rama & 0.1715 & 40.91 & 0.1866 & 47.06 & 0.0390 & 40.00 & 0.3213 & 61.54 & 0.0000 & 0.00 \\
\hline January & 0.0892 & 38.64 & 0.0480 & 41.18 & 0.2031 & 60.00 & 0.1011 & 38.46 & 0.0867 & 22.22 \\
\hline Ramadan x January & 0.0836 & 27.27 & 0.1403 & 29.41 & -0.1881 & 20.00 & -0.0265 & 30.77 & 0.2864 & 22.22 \\
\hline AFC & -0.0338 & 27.27 & -0.0131 & 47.06 & -0.1185 & 40.00 & -0.0516 & 15.38 & 0.0000 & 0.00 \\
\hline GFC & 0.0194 & 45.45 & 0.1652 & 58.82 & -0.1060 & 60.00 & -0.0769 & 38.46 & -0.0471 & 22.22 \\
\hline
\end{tabular}

Note: This summary table shows the average coefficients of lagged return, Ramadan, January, the interaction between Ramadan and January, the AFC and the GFC in the mean equation for firms in all five sectors of Indonesia, Jordan, Pakistan and Turkey. Coef. shows the average of coefficients whilst \%Sig shows the percentage of firms in the sector that has significant coefficients at 5 percent level. To conserve space, only the Ramadan and January effects, the crisis effects and the lagged return effect is reported in this table. Emboldened numbers are exceptions (the result is different from the expectation). The full estimation results are available from the authors upon request. 
Table 7: EGARCH Results for Variance Equation: Sectorial Analysis by Country

\begin{tabular}{|c|c|c|c|c|c|c|c|c|c|c|}
\hline \multirow[t]{2}{*}{ Variables } & \multicolumn{2}{|c|}{ All } & \multicolumn{2}{|c|}{ Indonesia } & \multicolumn{2}{|c|}{ Jordan } & \multicolumn{2}{|c|}{ Pakistan } & \multicolumn{2}{|c|}{ Turkey } \\
\hline & Coef. & \%Sig & Coef. & \%Sig & Coef. & \%Sig & Coef. & \%Sig & Coef. & $\% \mathrm{Sig}$ \\
\hline \multicolumn{11}{|l|}{ Finance } \\
\hline Ramadan & -0.0287 & 69.24 & -0.0116 & 82.76 & -0.0023 & 47.06 & -0.1037 & 81.25 & -0.0173 & 60.00 \\
\hline January & .0223 & 63.50 & -0.0371 & 72.41 & -0.0316 & 70.59 & -0.0268 & 2.50 & .0112 & 45.00 \\
\hline Ramadan x January & -0.0451 & 69.38 & -0.0898 & 79.31 & -0.0705 & 58.82 & -0.0516 & 1.25 & 0.0479 & 55.00 \\
\hline AFC & 0.0260 & 88.94 & 0.0545 & 93.10 & -0.0298 & 82.35 & 0.0150 & 87.50 & 0.0437 & 90.00 \\
\hline GFC & -0.0341 & 93.90 & -0.0844 & 96.55 & -0.0335 & 94.12 & 0.0909 & 87.50 & -0.0618 & 95.00 \\
\hline$\varepsilon_{j t-1} / \sqrt{h_{t-1}}$ & 0.0024 & 72.15 & 0.0042 & 82.76 & 0.0193 & 88.24 & -0.0073 & 68.75 & -0.0079 & 45.00 \\
\hline \multicolumn{11}{|l|}{ Industrial } \\
\hline Ramadan & -0.0504 & 63.74 & -0.0660 & 70.83 & -0.1981 & 66.67 & -0.0452 & 75.00 & -0.0196 & 51.35 \\
\hline January & 0.0052 & 61.54 & 0.0026 & 66.67 & -0.0608 & 50.00 & 0.0219 & 83.33 & 0.0068 & 45.95 \\
\hline Ramadan x J & -0.2773 & 75.82 & -0.9307 & 70.83 & -0.1432 & 100.0 & -0.2039 & 3.33 & 0.0771 & 70.27 \\
\hline $\mathrm{AFC}$ & 0.0504 & 89.01 & 0.1253 & 100.0 & -0.1242 & 83.33 & 0.0395 & 1.67 & 0.0371 & 81.08 \\
\hline GFC & -0.0672 & 89.01 & -0.0733 & 95.83 & -0.0131 & 66.67 & -0.1197 & 95.83 & -0.0380 & 83.78 \\
\hline$\varepsilon_{j t-1} / \sqrt{h_{t-1}}$ & 0.0127 & 63.74 & 0.0126 & 91.67 & 0.0170 & 66.67 & 0.0252 & 62.50 & 0.0039 & 45.95 \\
\hline \multicolumn{11}{|l|}{ Utilities } \\
\hline Ramadan & -0.0366 & 66.67 & -0.0179 & 54.55 & -0.0524 & 100.0 & -0.0596 & 72.73 & -0.0256 & 60.00 \\
\hline January & -0.0296 & 58.34 & -0.0612 & 63.64 & -0.0254 & 50.00 & -0.0428 & 54.55 & 0.0179 & 60.00 \\
\hline Ramadan x Ja & 0.0236 & 63.89 & 0.0553 & 72.73 & 0.0000 & 0.00 & -0.0407 & 63.64 & 0.0688 & 80.00 \\
\hline $\mathrm{AFC}$ & 0.0645 & 91.67 & 0.1633 & 90.91 & 0.0352 & 50.00 & 0.0105 & 100.0 & 0.0271 & 100.0 \\
\hline GFC & -0.0725 & 86.11 & -0.1311 & 81.82 & 0.0054 & 75.00 & -0.0717 & 100.0 & -0.0399 & 80.00 \\
\hline$\varepsilon_{j t-1} / \sqrt{h_{t-1}}$ & $0.0000^{*}$ & 83.33 & 0.0038 & 90.91 & 0.0442 & 75.00 & -0.0043 & 81.82 & -0.0170 & 80.00 \\
\hline \multicolumn{11}{|l|}{ Consumer } \\
\hline Rame & .0754 & 67.25 & -0.1507 & 73.13 & -0.0742 & 66.67 & -0.0298 & 71.11 & -0.0158 & 56.00 \\
\hline January & -0.0510 & 67.84 & -0.0778 & 80.60 & -0.0541 & 55.56 & -0.0677 & 82.22 & 0.0005 & 40.00 \\
\hline Ramadan x January & -0.2586 & 71.35 & 0.1075 & 70.15 & -0.1422 & 77.78 & -1.1960 & 80.00 & 0.0736 & 64.00 \\
\hline $\mathrm{AFC}$ & 0.0257 & 85.38 & 0.1423 & 95.52 & -0.0352 & 66.67 & -0.1498 & 91.11 & 0.0384 & 70.00 \\
\hline GFC & -0.1058 & 92.40 & -0.2006 & 92.54 & -0.0036 & 77.78 & -0.0352 & 93.33 & -0.0608 & 94.00 \\
\hline$\varepsilon_{j t-1} / \sqrt{h_{t-1}}$ & 0.0115 & 66.67 & 0.0076 & 77.61 & 0.0220 & 44.44 & 0.0225 & 73.33 & 0.0049 & 50.00 \\
\hline \multicolumn{11}{|l|}{ Chemical } \\
\hline & 9797 & 75.00 & -0.0682 & & -0.0451 & 60.00 & -0.1539 & 84.62 & -0.0133 & 44.44 \\
\hline January & -0.0493 & 63.64 & -0.0856 & 76.47 & 0.0986 & 100.0 & -0.0943 & 69.23 & 0.0022 & 11.11 \\
\hline Ramadan x January & -0.3989 & 52.27 & -0.3291 & 47.06 & -0.1172 & 40.00 & -0.9095 & 61.54 & 0.0502 & 55.56 \\
\hline $\mathrm{AFC}$ & 0.0641 & 95.46 & 0.1159 & 100.0 & -0.0001 & 100.0 & 0.0456 & 92.31 & 0.0286 & 88.89 \\
\hline GFC & -0.1217 & 86.37 & -0.2307 & 88.24 & -0.0068 & 100.0 & -0.0732 & 69.23 & -0.0495 & 100.0 \\
\hline$\varepsilon_{j t-1} / \sqrt{h_{t-1}}$ & 0.0087 & 54.55 & 0.0125 & 70.59 & 0.0000 & 0.00 & 0.0173 & 69.23 & -0.0061 & 33.33 \\
\hline
\end{tabular}

Note: This summary table shows the average coefficients of Ramadan, January, the interaction between Ramadan and January, the AFC, the GFC and the leverage in the variance equation for firms in all five sectors of Indonesia, Jordan, Pakistan and Turkey. Coef. shows the average of coefficients whilst \%Sig shows the percentage of firms in the sector that has significant coefficients at 5 percent level. To conserve space, only the Ramadan and January effects, the crisis effects and the leverage effect is reported in this table. Emboldened numbers are exceptions (the result is different from the expectation). The full estimation results are available from the authors upon request.

* The average value of coefficients is zero, but the percentage of firms that have a significant leverage effect is high. 